\title{
KAITAN RUANG TERBUKA HIJAU DENGAN KENYAMANAN TERMAL PERKOTAAN
}

\author{
THE RELATIONSHIP OF GREEN OPEN SPACE WITH HUMAN COMFORT IN URBAN AREAS
}

\author{
Sobri Effendy* dan Ferdy Aprihatmoko \\ Departemen Geofisika dan Meteorologi, \\ Gedung FMIPA, Jl. Meranti Wing 19 Lv.4 Kampus IPB Darmaga, Bogor 16680 \\ * Corresponding author, email: sobrieffendy2001@yahoo.com
}

Penyerahan Naskah: 6 Desember 2013

Diterima untuk diterbitkan: 4 Februari 2014

\begin{abstract}
The existence of green open space in urban areas is very important in influencing the conditions of thermal comfort. The objective of this research was to analyze the relationship between green open space and human comfort for the city of Yogyakarta. We employed Temperature Humidity Index (THI) with input air temperature and relative humidity. The THI value was obtained from four green open space categories those are point, line, area and non-green space. The results showed that the green open space has a positive effect on lowering the air temperature through the cooling effect and providing more comfortable conditions than the place with non-green open space. Based on this research, the city of Yogyakarta could be categorized as quite comfortable.
\end{abstract}

Keywords: air temperature, green open space, human comfort, temperature humidity index, thermal comfort

Sitasi: Effendy S. dan Aprihatmoko F. 2014. Kaitan ruang terbuka hijau dengan kenyamanan termal perkotaan. J Agromet Indonesia. 28(1):23-32.

\section{PENDAHULUAN}

Perluasan wilayah perkotaan berdampak terhadap kondisi di perkotaan seperti perubahan kondisi iklim mikro dan kondisi lingkungan yang semakin buruk (Effendy et al., 2006; Effendy, 2009; Oliveira et al., 2011). Kota Yogyakarta merupakan wilayah di Indonesia yang berkembang pesat. Tingkat perkembangan pembangunan yang pesat di berbagai sektor cenderung mengakibatkan penurunan ketersediaan ruang terbuka hijau (RTH). Berdasarkan Undang-Undang No. 26 (2007) tentang Penataan Ruang, wilayah kota harus menyediakan RTH yang terdiri dari RTH publik dan RTH privat. Proporsi RTH minimal 30\% dari luas wilayah kota dengan proporsi RTH publik pada wilayah kota paling sedikit $20 \%$ dari luas wilayah kota.

Ruang terbuka hijau tidak hanya memberikan manfaat dalam aspek ekologi, sosial, budaya, ekonomi, dan estetika, namun juga aspek iklim mikro di wilayah tersebut. Effendy et al. (2006) dan Effendy (2009) menjelaskan bahwa terjadi peningkatan suhu udara pada wilayah yang mengalami penurunan RTH.
Peningkatan suhu udara mempengaruhi kenyamanan termal bagi populasi yang tinggal di wilayah tersebut. Salah satu metode yang dapat digunakan untuk mengkaji tingkat kenyamanan suatu wilayah adalah metode Temperature Humidity Index (THI). Metode ini menghasilkan suatu indeks untuk menetapkan efek dari kondisi panas terhadap kenyamanan manusia berdasarkan unsur suhu dan kelembapan udara.

Perubahan suhu, wilayah bervegetasi, dan kenyamanan termal saling berkaitan. Gomez et al. (2004) menjelaskan bahwa areal bervegetasi memiliki peranan penting dalam mempengaruhi albedo dan nilai dari radiasi surya yang sampai ke wilayah perkotaan. Hal tersebut berkorelasi positif terhadap kenyamanan manusia jika dilihat dari indeks kenyamanan yang dihasilkan.

Konsep mengenai zona hijau (green zone) yang mempengaruhi kenyamanan juga telah dikaji oleh Setyowati (2008) di kota Semarang. Setyowati (2008) menjelaskan bahwa tegakan vegetasi yang kurang sebagai perindang yang ditanam di sepanjang jalan menyebabkan keadaan iklim mikro yang cukup panas dan kering. 
Berdasarkan hal-hal tersebut maka penelitian ini dilakukan untuk mengkaji hubungan antara RTH terhadap indeks kenyamanan dengan studi kasus di wilayah Kota Yogyakarta. Adapun tujuan dari penelitian ini adalah: (1) mengetahui suhu udara di beberapa wilayah yang mewakili Ruang Terbuka Hijau (RTH) dan lahan terbangun (non-RTH) di wilayah Kota Yogyakarta, (2) menganalisis kaitan ruang terbuka hijau (RTH) dengan suhu udara di Kota Yogyakarta, (3) menganalisis kaitan ruang terbuka Hijau (RTH) dengan kenyamanan termal di Kota Yogyakarta.

\section{METODE PENELITIAN}

\section{Tempat dan Waktu Penelitian}

Kota Yogyakarta merupakan pusat kota yang berada di Propinsi Daerah Istimewa Yogyakarta. Kota ini terletak pada $7^{\circ} 49^{\prime} 26^{\prime \prime}-7^{\circ} 15^{\prime} 24$ ' lintang selatan dan $110^{\circ} 24^{\prime} 19^{\prime \prime}-110^{\circ} 28^{\prime} 53^{\prime \prime}$ bujur timur pada ketinggian rata-rata $114 \mathrm{mdpl}$. Luas yang dimiliki oleh Kota Yogyakarta adalah 3.250 ha $(32,5$ $\mathrm{km}^{2}$ ) atau $1,02 \%$ dari luas wilayah Propinsi Daerah Istimewa Yogyakarta. Tipe iklim Kota Yogyakarta adalah Am dan Aw, atau monsoon dan dry tropical rain forest. Suhu rata-rata sebesar $27,2^{\circ} \mathrm{C}$, kelembapan rata-rata $75 \%$, curah hujan rata-rata $2012 \mathrm{~mm} /$ tahun dengan rata-rata kecepatan angin sebesar 9,5-29,7 km/jam.

Kota Yogyakarta sebagai salah satu pusat perkotaan di Daerah Istimewa Yogyakarta memiliki taman, perindang jalan, dan kawasan hijau lain yang tersebar di seluruh bagian kota. Keputusan Walikota Yogyakarta No. 619 (2007) tentang Rencana Aksi Daerah Peningkatan Kualitas Lingkungan Kota Yogyakarta Tahun 2007-2011, menyebutkan bahwa saat ini ruang teruka hijau (RTH) yang dimiliki Kota Yogyakarta adalah sebagai berikut:

a. Luas jalur hijau dan taman kota sebesar 73.036 $\mathrm{m}^{2}$ (yang dikelola pemerintah),

b. Jumlah pohon perindang sebanyak 4.863 pohon pada jalur jalan,

c. Luas RTH (s/d tahun 2007) berupa jalur hijau sebesar $59.232 \mathrm{~m}^{2}$, taman sebesar $128.682 \mathrm{~m}^{2}$, dan ruang terbuka hijau kawasan perkotaan lainnya yang dikelola publik (pemakaman umum, lapangan olahraga, parkir terbuka, sempadan sungai, jalur pengaman jalan, media jalan, rel kereta api dan pedestrian, taman lingkungan kantor dan komersial) sebesar $1.626 .979 \mathrm{~m}^{2}$,

d. luas RTH privat (s/d tahun 2007) sebesar $2.868 .094 \mathrm{~m}^{2}$ yang meliputi taman kebun binatang, taman lingkungan perumahan dan pemukiman, lahan pertanian perkotaan, dan sempadan bangunan.

Pengambilan data suhu udara dilakukan di wilayah RTH, khususnya tanaman dengan tinggi batang lebih dari 3 (tiga) meter, dan wilayah nonvegetasi. Pengambilan sampel untuk variabel sebaran vegetasi meliputi delapan lokasi. Lokasi tersebut berupa enam wilayah RTH yang berada di wilayah perkotaan dan dua lokasi yang mewakili lahan terbangun (Gambar 1). Wilayah yang dikaji merujuk kepada sebaran vegetasi berupa RTH dikelompokkan menjadi tiga yaitu RTH Titik, RTH Garis, RTH Area, dan kawasan Non-RTH.

- RTH Titik berupa tegakan vegetasi (pohon) yang ditanam di pekarangan Kraton, Kelurahan Kadipaten, Kecamatan Kraton.

- RTH Titik berupa tegakan vegetasi (pohon) yang ditanam di pertokoan Malioboro, Jalan Malioboro Kelurahan Danurejan Kecamatan Sosrokusuman.

- RTH Garis berupa vegetasi (pohon) yang ditanam sepanjang areal yang lurus yang berada di sepanjang jalan di Jalan Jenderal Sudirman.

- RTH Garis berupa vegetasi (pohon) yang ditanam sepanjang areal yang lurus di sekitar sungai di Sungai Winongo, Kelurahan Kricak, Kecamatan Tegal Rejo.

- RTH Area berupa vegetasi (pohon) yang memiliki sebaran yang lebih besar yaitu di kawasan pemakaman umum Kelurahan Tahunan, Kecamatan Umbul Harjo.

- RTH Area berupa vegetasi (pohon) yang memiliki sebaran yang lebih besar yaitu di kebun binatang Gembiraluko.

- Wilayah non-vegetasi berupa area yang tidak ditumbuhi vegetasi di pusat pertokoan Jl. P Mangkubumi Kecamatan Jetis.

- Wilayah non-vegetasi berupa area yang tidak ditumbuhi vegetasi di sekitar pertokoan yang dekat dengan perumahan di Jalan Matraman.

Pengambilan data suhu udara di lokasi pengamatan dilakukan dari tanggal 7 Juli 2012 hingga 15 Agustus 2012 yang bertujuan untuk mewakili bulan-bulan kering di Indonesia khususnya di kota Yogyakarta.

\section{Alat dan Bahan \\ Pengambilan data suhu udara didasarkan observasi pada lokasi pengamatan dengan menggunakan alat ukur suhu udara berupa termometer digital yang dapat mengukur suhu bola kering dan bola basah yang dibuat dari sensor panas LM35.}



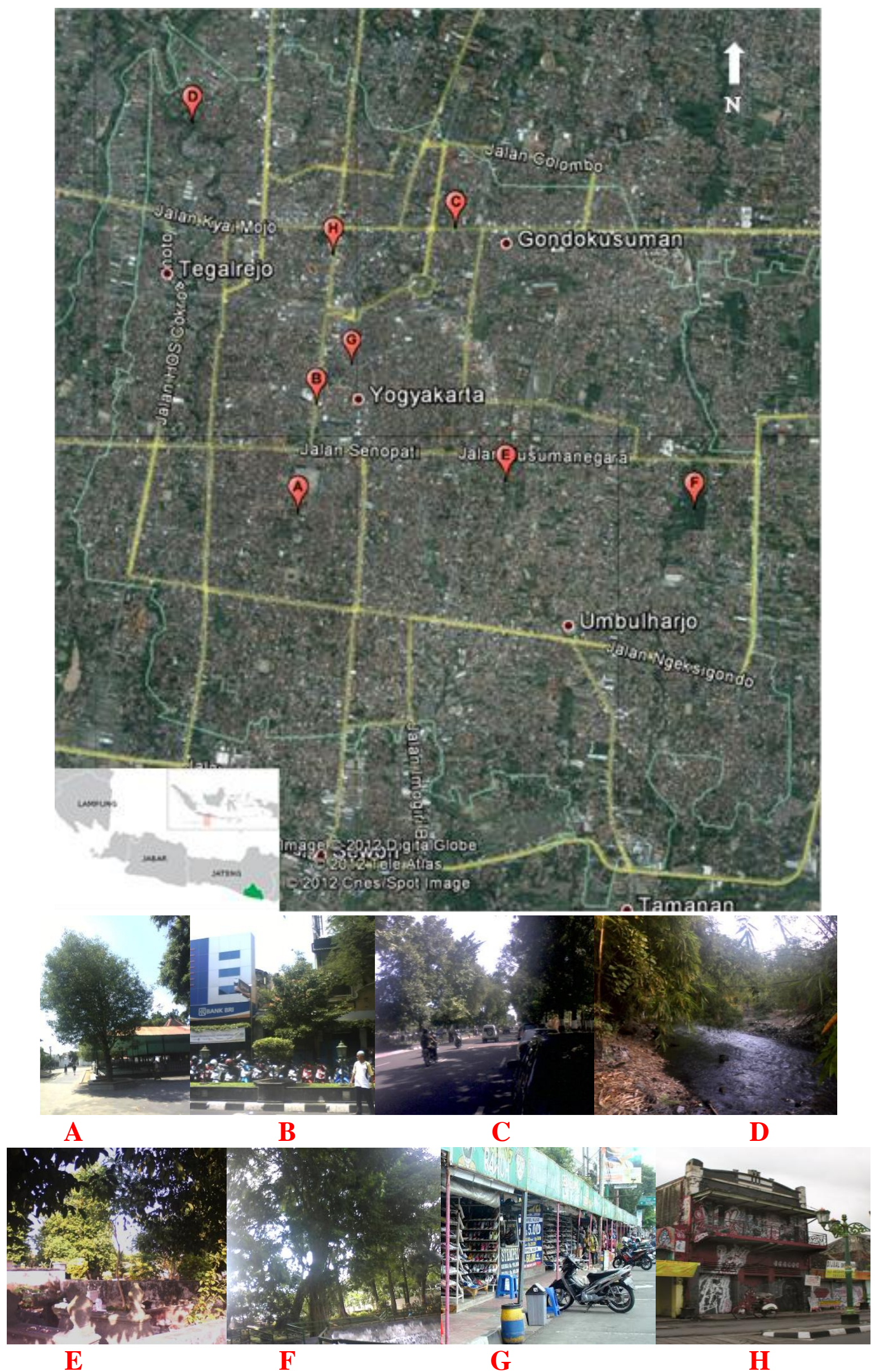

Gambar 1. Lokasi pengamatan RTH dan lahan terbangun di Kota Yogyakarta (Sumber: Google Earth dengan tanggal pencitraan 26 Juni 2007 dan dokumentasi pribadi). 


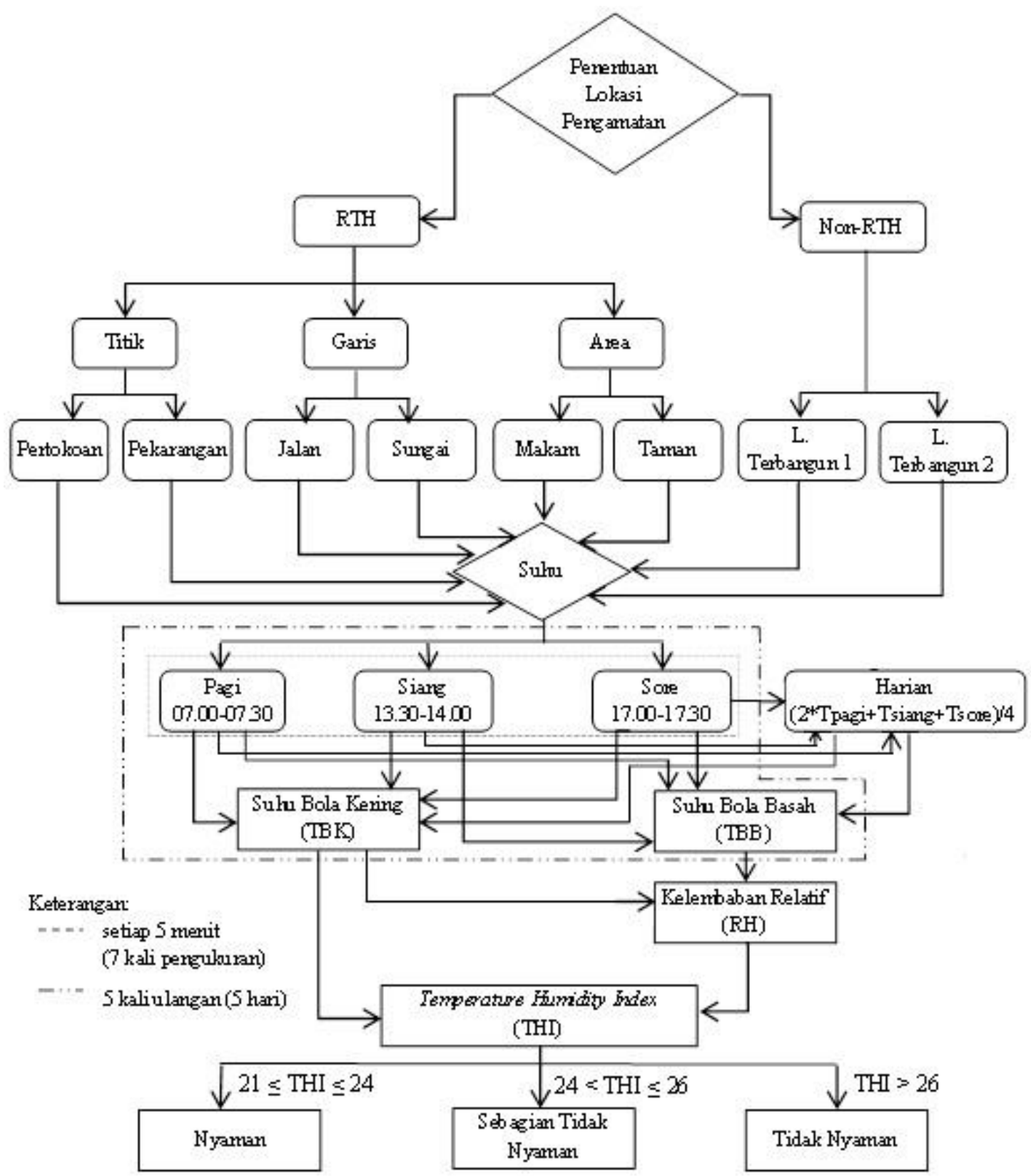

Gambar 2. Diagram alir penelitian.

\section{Tahapan Penelitian}

Prosedur penelitian disajikan pada diagram alir pada Gambar 2. Penentuan sampel untuk sebaran vegetasi ditentukan menjadi empat wilayah, yaitu RTH Titik (pekarangan dan pertokoan), RTH Garis (jalan dan sungai), RTH Area (makan dan kebun binatang), dan kawasan non-RTH. Setiap titik pengamatan dalam satu hari dilakukan 3 (tiga) kali pengukuran yaitu pada pukul 07.00-07.30 WIB untuk mewakili pagi hari, pukul 13.30-14.00 WIB untuk mewakili siang hari dan kondisi suhu tertinggi diurnal, dan pukul 17.00-17.30 WIB untuk mewakili sore hari. Pengambilan data suhu udara untuk setiap waktu yang mewakili pagi hari, siang hari dan sore hari dilakukan setiap 5 (lima) menit (7 kali pengambilan data) dan setiap lokasi pengamatan dilakukan ulangan sebanyak 5 (lima) kali pengulangan sehingga jumlah pengukuran sebanyak 8 lokasi $\times 3$ waktu pengukuran $\times 7$ kali pengambilan data $\times 5$ kali pengulangan $=840$ kali pengukuran.

Setiap lokasi pengamatan dilakukan pengukuran setiap hari yang berbeda dengan asumsi bahwa memiliki kondisi cuaca yang sama setiap hari selama pengukuran.

Parameter iklim mikro yang diamati pada lokasi penelitian meliputi: (1) suhu bola kering dan bola basah yang diperoleh dari pengukuran pada termometer suhu udara, (2) kelembapan relatif yang diperoleh dari Persamaan (1) sampai (4):

$$
\begin{aligned}
& e_{(t)}(T)=6,108 \exp \left(\frac{17,269 T_{b t}}{237,3+T_{b c}}\right) \\
& e_{(}(T w)=6,108 \exp \left(\frac{17,269 T_{b b}}{237,3+T_{b i}}\right)
\end{aligned}
$$




$$
\begin{aligned}
& e_{a}=e_{s}(T w)-\left(0,661\left(T_{b k}-T_{b b}\right)\right) \\
& R H=\frac{e_{s}(T)}{e_{a}} \times 100
\end{aligned}
$$

dimana $e_{s}(T)$ adalah tekanan uap jenuh pada suhu bola kering, $e_{s}(T w)$ adalah tekanan uap jenuh pasa suhu bola basah, $e_{a}$ adalah nilai tekanan uap aktual dengan angka 0,661 merupakan sebuah konstanta psikometri, $T_{b k}$ (dalam ${ }^{\circ} \mathrm{C}$ ) adalah suhu bola kering yang diperoleh dari hasil pengukuran, $T_{b b}$ (dalam ${ }^{\circ} \mathrm{C}$ ) adalah suhu bola basah yang diperoleh dari hasil pengukuran dan $\mathrm{RH}$ (dalam \%) adalah kelembapan relatif. (3) Indeks kenyamanan, penentukan indeks kenyamanan pada penelitian ini berdasarkan persamaan dari Nieuwolt (1975) dalam Kakon et al. (2010) yang menggunakan indikator Temperature Humidity Index (THI). Penentuan indeks kenyamanan THI tersebut menghubungkan antara kondisi suhu udara dan kelembapan udara pada suatu wilayah yang akan mempengaruhi kondisi panas di sekitar sehingga akan mempengaruhi kenyamanan manusia (human comfort).

Penentuan indeks kenyamanan berdasarkan indikator Temperature Humidity Index (THI) tersebut menggunakan Persamaan (5).

$$
T H I=0,8 T_{a}+\left(\frac{R H \times T_{a}}{500}\right)
$$

dimana THI adalah Indeks kenyamanan, $\mathrm{T}_{\mathrm{a}}$ adalah suhu udara didapat dari suhu bola kering $\left({ }^{\circ} \mathrm{C}\right)$, dan $\mathrm{RH}$ adalah kelembapan udara (dalam \%) diperoleh dari hasil perhitungan.

Rentang nilai indeks kenyamanan yang didapat dari persamaan Nieuwolt yang diaplikasikan di Colombo Sri Lanka (Emmanuel, 2005) dihasilkan penilaian responden manusia dengan rentang nilai sebagai berikut:

$21 \leq \mathrm{THI} \leq 24=100 \%$ responden merasa nyaman $25 \leq \mathrm{THI} \leq 26=50 \%$ responden merasa nyaman

$\mathrm{THI}>26=0 \%$ responden merasa nyaman

Nilai THI untuk menentukan kenyamanan manusia diperoleh berdasarkan fisiologi manusia yang dihubungkan dengan kondisi lingkungan sekitar manusia tersebut.

\section{HASIL DAN PEMBAHASAN}

\section{Kondisi Suhu Udara di Lokasi Pengamatan}

Suhu udara dari hasil pengamatan merupakan gambaran dari suhu udara dalam empat kondisi. Empat kondisi tersebut adalah suhu udara yang mewakili pagi hari, siang hari, sore hari, dan suhu udara harian. Nilai suhu udara yang terukur pada kawasan RTH dan non-RTH dari empat kondisi tersebut menunjukkan suhu udara yang berbeda.

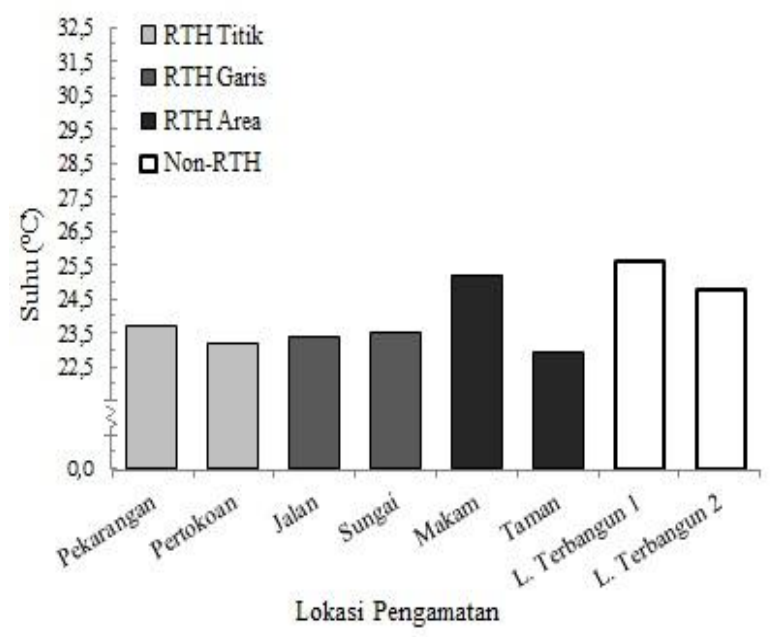

Gambar 3. Suhu udara pada pagi hari di delapan lokasi pengamatan.

Suhu udara pada pagi hari di delapan lokasi pengamatan menunjukkan nilai pada rentang 22,9$25,6^{\circ} \mathrm{C}$ (Gambar 3). Suhu udara pada pagi hari di kawasan RTH Titik sebesar $23,7^{\circ} \mathrm{C}$ untuk pekarangan dan $23,2^{\circ} \mathrm{C}$ untuk pertokoan. Nilai suhu udara pada pagi hari di kawasan RTH Garis adalah sebesar $23,4^{\circ} \mathrm{C}$ untuk jalan dan $23,5^{\circ} \mathrm{C}$ untuk sungai. Suhu udara pagi hari di kawasan RTH Area memiliki selisih yang lumayan besar yaitu $25,2^{\circ} \mathrm{C}$ untuk di makam dan $22,9^{\circ} \mathrm{C}$ untuk di taman. Sedangkan nilai suhu udara pada pagi hari yang terukur di lahan terbangun (non-RTH) memiliki nilai yang lebih tinggi dibandingkan dengan daerah yang memiliki RTH. Suhu udara pada pagi hari di lahan terbangun 1 sebesar $25,6^{\circ} \mathrm{C}$ dan di lahan terbangun 2 sebesar $24,8^{\circ} \mathrm{C}$.

Peningkatan suhu udara terjadi di semua lokasi pengamatan pada siang hari. Waktu pengambilan suhu udara pada siang hari adalah dari pukul 13.30 WIB - 14.00 WIB yang diharapkan dapat mewakili kondisi suhu tertinggi dalam satu hari. Suhu udara pada siang hari di delapan lokasi pengamatan memiliki rentang nilai dari $27,9^{\circ} \mathrm{C}$ hingga $35,3^{\circ} \mathrm{C}$ (Gambar 4). Suhu udara pada siang hari di kedua kawasan RTH Titik tidak terlalu jauh yaitu sebesar $29,4^{\circ} \mathrm{C}$ untuk pekarangan dan $29,9^{\circ} \mathrm{C}$ untuk pertokoan. Nilai suhu udara pada siang hari di kawasan RTH Garis adalah sebesar $29,0^{\circ} \mathrm{C}$ untuk jalan dan $27,9^{\circ} \mathrm{C}$ untuk sungai. Suhu udara siang hari di kawasan RTH Area memiliki nilai sebesar $29,3^{\circ} \mathrm{C}$ untuk di makam dan $28,3^{\circ} \mathrm{C}$ untuk di taman. Sedangkan nilai suhu udara pada siang hari yang terukur di lahan terbangun (non-RTH) memiliki nilai yang lebih tinggi dibandingkan dengan daerah yang memiliki RTH. Suhu udara pada siang hari di lahan terbangun 1 sebesar $35,3^{\circ} \mathrm{C}$ dan di lahan terbangun 2 sebesar $35,0^{\circ} \mathrm{C}$. 


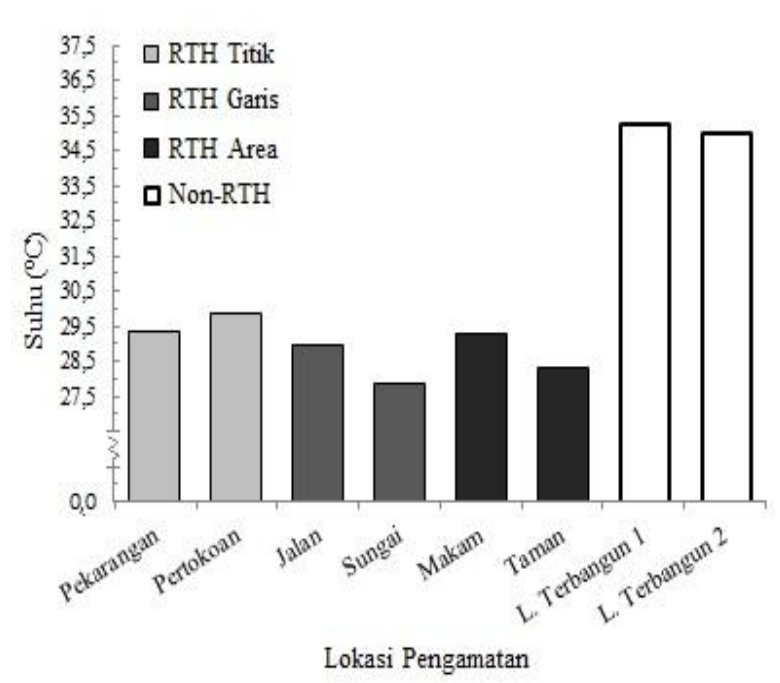

Gambar 4. Suhu udara pada siang hari di delapan lokasi pengamatan.

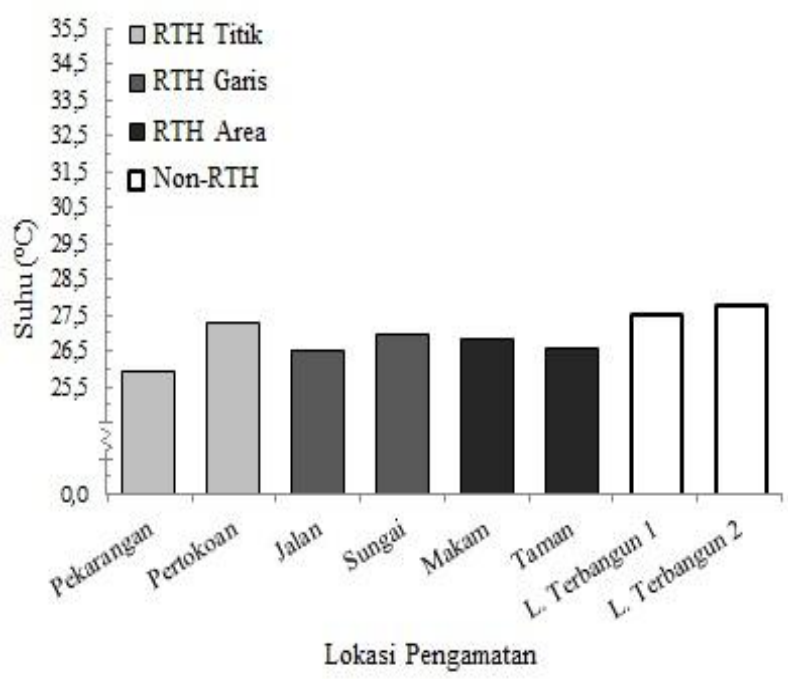

Gambar 5. Suhu udara pada sore hari di delapan lokasi pengamatan.

Hasil pengukuran suhu udara pada sore hari menunjukan nilai yang lebih rendah dibandingkan suhu udara pada siang hari namun tetap lebih tinggi dari pagi hari. Rentang nilai suhu udara pada sore hari di delapan lokasi pengamatan berkisar antara 25,9-27, $8^{\circ} \mathrm{C}$ (Gambar 5). Suhu udara pada sore hari di kawasan RTH Titik sebesar $25,9^{\circ} \mathrm{C}$ untuk pekarangan dan $27,3^{\circ} \mathrm{C}$ untuk pertokoan. Nilai suhu udara pada sore hari di kawasan RTH Garis yaitu $26,5^{\circ} \mathrm{C}$ untuk jalan dan $26,9^{\circ} \mathrm{C}$ untuk sungai. Suhu udara sore hari di kawasan $\mathrm{RTH}$ Area yaitu $26,8^{\circ} \mathrm{C}$ untuk di makam dan $26,6^{\circ} \mathrm{C}$ untuk di taman. Sedangkan jika dibandingkan dengan suhu udara di pagi dan siang hari, nilai suhu udara pada sore hari yang terukur di lahan terbangun (non-RTH) memiliki selisih nilai yang tidak terlalu tinggi dibandingkan dengan daerah yang memiliki RTH. Suhu udara pada siang hari di lahan terbangun 1 sebesar $27,5^{\circ} \mathrm{C}$ dan di lahan terbangun 2 sebesar $27,8^{\circ} \mathrm{C}$.
Hasil pengukuran yang diperoleh menunjukkan bahwa pada pagi hari suhu udara akan lebih rendah kemudian akan meningkat hingga siang hari dan akan mencapai maksimum sekitar pukul 14.00 WIB atau setelah radiasi maksimum terjadi. Hal ini sesuai dengan yang dijelaskan oleh Handoko (1993) yang menyatakan bahwa pada variasi diurnal suhu maksimum tercapai sekitar pukul 14.00 waktu setempat yaitu setelah radiasi maksimum terjadi karena adanya pemanasan udara yang masih berlangsung terus meskipun radiasi surya maksimum telah terjadi sekitar pukul 12.00 waktu setempat.

Tjasyono (2008) juga menjelaskan bahwa peningkatan suhu udara pada variasi diurnal berkaitan dengan posisi/tingginya matahari yang kemudian akan mempengaruhi penyebaran radiasi matahari yang dapat memanaskan suhu udara. Semakin menuju siang hari maka posisi matahari akan semakin tinggi. Jika matahari tinggi maka radiasi yang jatuh hampir tegak lurus pada permukaan bumi sehingga radiasi akan disebarkan di dalam area yang lebih sempit.

Suhu udara pada sore hari dari hasil pengamatan yang diperoleh menunjukan bahwa suhu udara di seluruh wilayah kajian akan menjadi lebih rendah dibandingkan dengan siang hari. Kondisi tersebut dikarenakan perubahan posisi matahari yang semakin rendah pada sore hari dibandingkan pada siang hari. Jika matahari rendah maka sinar matahari akan melalui atmosfer yang lebih tebal dimana terjadi banyak hamburan dan penyerapan serta penyebaran radiasinya pun terjadi dalam area yang lebih luas (Tjasyono, 2008). Selain itu Handoko (1993) menjelaskan bahwa ketika suhu udara telah mencapai maksimum di siang hari maka suhu udara akan turun kembali hingga mencapai suhu minimum di pagi hari (sekitar pukul 04.00 waktu setempat). Hal ini disebabkan karena setelah suhu maksimum tercapai maka radiasi yang keluar akan lebih besar dari radiasi yang datang sehingga radiasi yang datang yang digunakan untuk memanaskan suhu udara di sore hari akan menjadi semakin sedikit dibandingkan pada siang hari.

Gambar 6 menunjukan kondisi suhu udara harian yang terdapat di delapan lokasi pengamatan. Rentang nilai suhu udara pada delapan lokasi pengamatan antara $25,2-28,5^{\circ} \mathrm{C}$. Suhu udara harian tertinggi berdasarkan katogeri RTH dimiliki oleh kawasan non-RTH yaitu $28,5^{\circ} \mathrm{C}$ untuk lahan terbangun 1 dan $28,1^{\circ} \mathrm{C}$ untuk lahan terbangun 2 . Sedangkan daerah RTH Titik memiliki suhu udara untuk pekarangan sebesar $25,7^{\circ} \mathrm{C}$ dan pertokoan sebesar $25,9^{\circ} \mathrm{C}$. Daerah RTH Garis yang berupa jalan dan sungai memiliki suhu udara harian secara berurut sebesar $25,6^{\circ} \mathrm{C}$ dan $25,5^{\circ} \mathrm{C}$. Daerah yang memiliki RTH lebih luas seperti makam memiliki nilai suhu udara harian sebesar $26,6^{\circ} \mathrm{C}$, sedangkan 
daerah berupa taman memiliki suhu udara harian sebesar $25,2^{\circ} \mathrm{C}$. Berdasarkan hasil yang diperoleh sebaran suhu udara di lokasi pengamatan menunjukan bahwa kawasan yang memiliki RTH akan memiliki suhu udara yang lebih rendah dibandingkan dengan kawasan yang tidak memiliki RTH baik itu di pagi hari, siang hari, sore hari maupun untuk suhu harian.

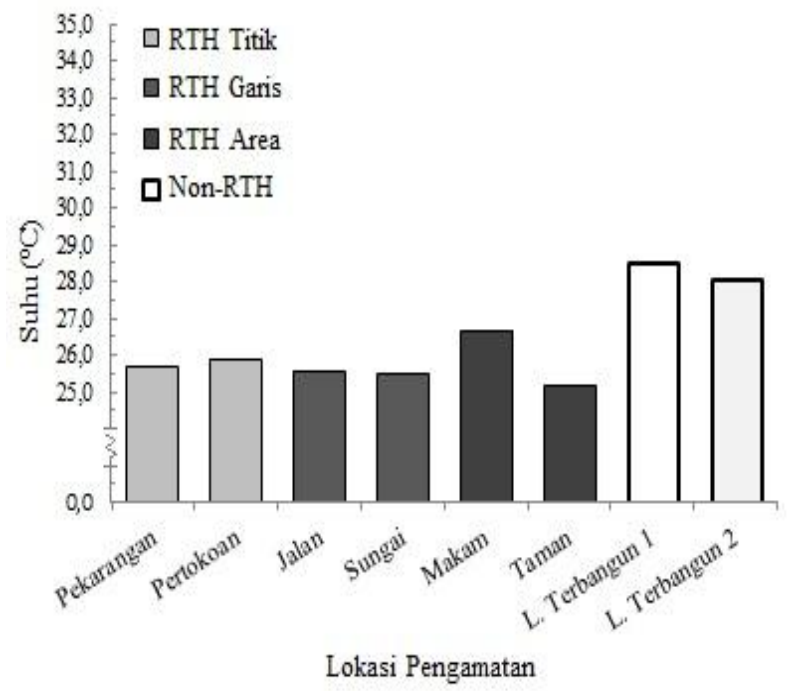

Gambar 6. Suhu udara harian di delapan lokasi pengamatan.

\section{Pengaruh Ruang Terbuka Hijau (RTH) terhadap Suhu Udara}

Suhu udara yang diperoleh pada masingmasing lokasi pengamatan menunjukkan nilai suhu udara yang berbeda (Tabel 1). Perbedaan suhu udara dipengaruhi oleh adanya RTH pada masing-masing lokasi pengamatan. Suhu udara terendah pada pagi hari dimiliki oleh RTH taman yaitu sebesar $22,9^{\circ} \mathrm{C}$. Suhu udara terendah pada siang hari adalah RTH di sungai yaitu $27,9^{\circ} \mathrm{C}$ dan pada sore hari suhu udara terendah dimiliki oleh RTH di pekarangan yaitu sebesar $25,9^{\circ} \mathrm{C}$. Suhu udara harian terendah dari masing-masing kategori RTH dimiliki oleh RTH area berupa taman yaitu sebesar $25,2^{\circ} \mathrm{C}$. Ukuran ruang terbuka hijau (RTH) akan menentukan besar kecilnya efek dari penurunan suhu udara (cooling effect) di lingkungan tersebut (Oliveira, 2012).

Pada penelitian ini nilai suhu udara harian terendah sesuai untuk daerah yang memiliki RTH yang lebih luas. Namun untuk kondisi di siang hari dan sore hari suhu udara di kawasan RTH Area berupa makam tetap telihat lebih tinggi dibandingkan dengan kawasan RTH lain yang luasnya lebih kecil. Kondisi ini dikarenakan kerapatan kanopi di lokasi makam tidak terlalu rapat. Kanopi yang renggang akan menyebabkan radiasi yang sampai ke area tersebut menjadi lebih banyak digunakan untuk memanaskan udara. Hal tersebut dijelaskan juga oleh Oliveira et al. (2012) dalam penelitiannya bahwa jika RTH yang lebih luas tidak memberikan cooling effect yang lebih besar daripada kawasan RTH yang lebih kecil maka hal tersebut dapat dijelaskan dari kombinasi beberapa faktor seperti: karakteristik yang terkandung di dalam suatu taman, dinding di sekitar RTH yang hampir menutupi kawasan tersebut, kondisi naungan atau faktor peneduh dari pohon dan bangunan di sekitar RTH, evaporasi yang intens serta rendahnya kecepatan angin.

Suhu udara di kawasan yang memiliki RTH dan yang tidak memiliki RTH jelas terlihat perbedaannya (Tabel 1). Hasil yang didapat berdasarkan Tabel 1 terlihat bahwa suhu udara tertinggi baik pagi, siang dan sore hari dimiliki oleh daerah yang tidak memiliki RTH. Hal tersebut menunjukkan bahwa kawasan RTH memiliki pengaruh terhadap kondisi suhu udara di daerah tersebut. Kawasan hijau (green zones) atau RTH akan memberikan pengaruh berupa pendinginan atau biasa disebut cooling effect. Cohen et al. (2012) menyebutkan bahwa beberapa studi mengenai pengaruh taman di perkotaan dapat menurunkan suhu udara di sekitar hingga $4^{\circ} \mathrm{C}$.

Tabel 1. Kondisi suhu udara berdasarkan kategori ruang terbuka hijau (RTH) di lokasi pengamatan.

\begin{tabular}{cllcccc}
\hline & \multirow{2}{*}{ Lokasi } & & \multicolumn{4}{c}{ Suhu $\left({ }^{\mathbf{0}} \mathbf{C}\right)$} \\
\cline { 3 - 6 } & & Pagi & Siang & Sore & Harian \\
\hline \multirow{6}{*}{ Titik } & Pekarangan & 23,7 & 29,4 & 25,9 & 25,7 \\
& & Pertokoan & 23,2 & 29,9 & 27,3 & 25,9 \\
\multirow{2}{*}{ RTH } & Garis & Jalan & 23,4 & 29,0 & 26,5 & 25,6 \\
& & Sungai & 23,5 & 27,9 & 26,9 & 25,5 \\
& \multirow{2}{*}{ Area } & Makam & 25,2 & 29,3 & 26,8 & 26,6 \\
& & Taman & 22,9 & 28,3 & 26,6 & 25,2 \\
& \multirow{2}{*}{ Non RTH } & Lahan Terbangun 1 & 25,6 & 35,3 & 27,5 & 28,5 \\
& Lahan Terbangun 2 & 24,8 & 35,0 & 27,8 & 28,1 \\
\hline
\end{tabular}


Kawasan RTH di daerah perkotaan akan memberikan pengaruh terciptanya cooling effect di sekitar dengan menurunkan suhu udara dan meningkatkan nilai kelembapan relatif (Oliveira et al., 2012; Cohen et al., 2010; Shahidan et al., 2010). Kawasan RTH yang memiliki penutupan kanopi dari pepohonan akan memberikan suatu kondisi naungan. Naungan tersebut dapat berfungsi untuk menghalangi radiasi matahari yang masuk di daerah tersebut sehingga radiasi matahari yang digunakan untuk pemanasan suhu udara akan semakin kecil. Hal ini sesuai dengan Shahidan et al. (2010) yang menjelaskan bahwa transmisi panas radiasi yang semakin kecil akibat penutupan kanopi pepohonan akan memberikan efek penurunan suhu udara permukaan tanah di bawah kanopi tersebut. Kondisi ini akan menaikan proses evapotranspirasi sehingga radiasi yang di gunakan untuk pemanasan suhu udara akan digunakan sebagian untuk evapotranspirasi. Faktor fisik dari kanopi berupa pohon dalam memodifikasi radiasi terhadap suhu udara udara serta memberikan naungan ditentukan dari sebaran cabang pohon dan penutupan oleh daun pada pohon tersebut.

Nilai suhu udara pada RTH jalan dan sungai menunjukan selisih yang besar. Hal ini karena lokasi di jalan memiliki aktivitas kendaraan yang padat sehingga pengaruh dari aktivitas kendaraan melemahkan pengaruh cooling effect di daerah tersebut. Keadaan seperti ini juga di jelaskan pada hasil penelitian Oliveira et al. (2012) yang menunjukkan bahwa suhu udara di kawasan RTH jalan lebih tinggi dibandingkan dengan RTH berbentuk area. Hal ini dijelaskan bahwa pada RTH jalan tersebut juga merupakan kawasan yang memiliki lalu lintas yang padat sehingga tingginya tingkat polusi udara dan panas yang keluar dari kendaraan akan meningkatkan suhu udara.

Suhu udara di siang hari dan sore hari serta nilai suhu udara harian di RTH pertokoan menunjukan hasil yang lebih tinggi dibandingkan dengan kawasan RTH lainnya (Tabel 1). Kondisi tersebut dapat dijelaskan oleh faktor kondisi di sekitar RTH. RTH Titik di daerah pertokoan maupun pekarangan berupa tegak sebuah pohon sehingga radiasi yang sampai ke permukaan akan lebih banyak dibandingkan radiasi yang di transmisikan oleh RTH di kawasan lain. Selain itu objek di di sekitar RTH pertokoan berupa gedung sehingga banyaknya radiasi yang terpantul yang kemudian akan digunakan untuk memanaskan suhu udara di area tersebut menjadi lebih besar.

\section{Pengaruh Ruang Terbuka Hijau (RTH) terhadap Kenyamanan Termal}

Penentuan indeks kenyamanan manusia yang diukur pada penelitian ini berdasarkan thermal comfort dengan metode Temperature Humidity Index (THI) yang menerapkan suhu udara dan kelembapan relatif. Nilai indeks yang dihitung berdasarkan persamaan Nieuwolt menghasilkan tiga kategori yaitu Nyaman, Sebagian Tidak Nyaman, dan Tidak Nyaman. Hasil yang diperoleh untuk kategori kenyamanan pada delapan lokasi pengamatan dilihat pada empat waktu yang berbeda yaitu pagi hari, siang hari, sore hari dan rata-rata harian. Kenyamanan yang didapat pada empat waktu tersebut menunjukan indeks yang berbeda (Gambar $6)$.

Pagi hari di kawasan RTH sebagian besar termasuk kedalam kategori nyaman sedangkan kawasan RTH makam dan lahan terbangun baik 1 maupun 2 termasuk kedalam kategori sebagian tidak nyaman (Gambar 7.a). Kawasan RTH akan memberikan kenyamanan di daerah tersebut dibandingkan dengan kawasan yang tidak memiliki RTH. Hal ini berkaitan dengan suhu udara dan kelembapan relatif yang terjadi di daerah tersebut. Kawasan RTH akan memberikan cooling effect sehingga nilai suhu udara di kawasan RTH akan lebih rendah dibandingkan dengan kawasan nonRTH. Shahidan et al. (2010) menjelaskan bahwa kawasan RTH akan mendapatkan radiasi yang lebih sedikit akibat adanya proses transmisi. Semakin sedikitnya radiasi yang diterima pada kawasan RTH akan memungkinkan terjadinya penurunan suhu udara dan peningkatan kelembapan relatif di sekitar sehingga dapat memperbaiki kenyaman termal manusia. RTH makam pada pagi hari menunjukan suhu udara yang lebih tinggi dibandingkan dengan suhu udara di kawasan RTH lain sehingga akan mempengaruhi panas yang terasa di daerah tersebut. Panas yang lebih tinggi di RTH makam akan menyebabkan kenyamanan yang lebih buruk dibandingkan dengan kawasan RTH lain

Kategori kenyamanan pada siang hari menunjukkan nilai pada rentang tidak nyaman untuk semua wilayah pengamatan (Gambar 7.b). Siang hari dengan suhu udara yang semakin meningkat akan memperburuk kondisi kenyamanan di wilayah tersebut. Suhu udara yang tinggi akan meningkatkan sensasi panas atau thermal comfort yang diterima oleh manusia akan menjadi lebih besar. Panas yang terasa oleh manusia akan mempengaruhi kenyamanan manusia. Sore hari kenyamanan yang dimiliki oleh hampir seluruh lokasi pengamatan berada pada kategori sebagian tidak nyaman kecuali pada lahan terbangun 2 yang memiliki kondisi tidak nyaman (Gambar 7.c). 


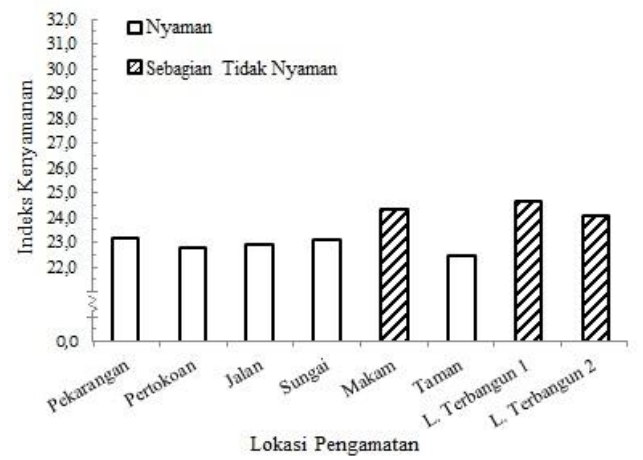

(a)

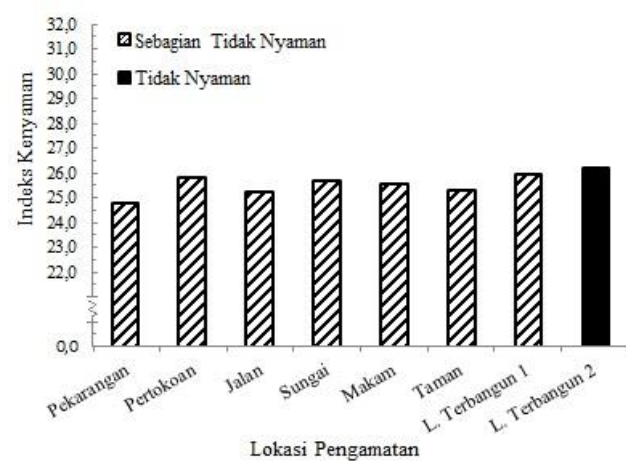

(c)

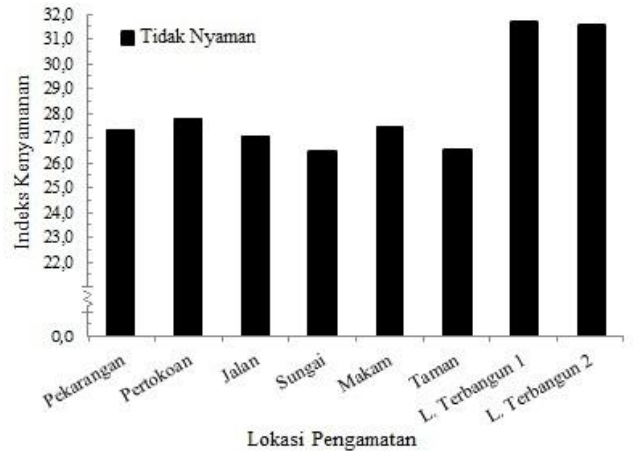

(b)

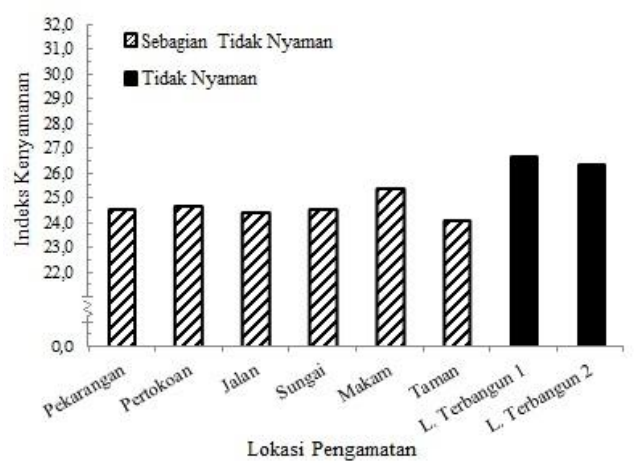

(d)

Gambar 7. Indeks kenyamanan di delapan lokasi pengamatan pada (a) pagi hari; (b) siang hari; (c) sore hari; dan (d) harian.

Suhu udara di sore hari akan menjadi lebih rendah dibandingkan dengan siang hari sehingga kenyamanan yang dihasilkan pada sore hari akan lebih membaik daripada di siang hari.

Suhu udara yang lebih panas pada kawasan non-RTH memberikan dampak kenyamanan yang lebih buruk di bandingkan dengan kawasan yang memiliki RTH pada siang hari. Hal ini disebabkan karena pada kawasan non-RTH tidak adanya penghalang radiasi yang masuk sehingga radiasi yang datang langsung diterima oleh permukaan. Nilai indeks kenyamanan harian menunjukkan bahwa kawasan RTH memiliki kategori sebagian tidak nyaman dibandingkan dengan kawasan nonRTH pada kategori tidak nyaman (Gambar 7.d). Keadaan tersebut akan memberikan kenyamanan yang lebih baik pada kawasan yang memiliki RTH dibandingkan dengan kawasan non-RTH. Naungan yang diberikan oleh pohon akan memberikan kenyamanan untuk manusia yang berada di bawahnya ketika melakukan aktivitas seperti duduk atau berjalan (Shahidan et al., 2010). Penanaman pohon yang dilakukan secara berkelompok akan memberikan manfaat yang lebih besar untuk menurunkan suhu udara dan suhu permukaan tanah. Penelitian ini juga menunjukan hasil yang sama yaitu suhu pada kawasan RTH yang lebih besar dan berkelompok (RTH Area) akan menghasilkan suhu udara yang lebih rendah dengan tingkat kenyamanan yang diperoleh pun akan menjadi lebih baik terlepas dari faktor yang mempengaruhi tingginya suhu udara di RTH makam.

Berdasarkan hasil yang didapat maka Kota Yogyakarta dapat dikatakan memiliki keadaan sebagian tidak nyaman. Penambahan RTH di Kota Yogyakarta perlu dilakukan untuk memperbaiki kondisi kenyamanannya. Hal tersebut karena dari hasil yang didapat pada penelitian ini menunjukkan bahwa RTH memiliki pengaruh positif terhadap kenyamanan manusia. Naungan yang diberikan oleh RTH akan memberikan nilai THI yang lebih kecil (lebih nyaman) dibandingkan dengan kawasan nonRTH. Oleh karena itu keberadaan RTH di perkotaan sangat penting untuk mengendalikan iklim mikro di perkotaan sehingga mendukung kondisi yang lebih nyaman di sebuah kota khususnya kota Yogyakarta.

\section{KESIMPULAN}

Sebaran suhu udara di lokasi pengamatan menunjukkan bahwa kawasan yang memiliki RTH memiliki suhu udara yang lebih rendah dibandingkan dengan kawasan non-RTH baik pagi, siang, sore maupun suhu udara harian. Suhu udara di pagi hari pada lokasi RTH memiliki rentang antara $22,9-25,2^{\circ} \mathrm{C}$, pada wilayah non-RTH $24,8-$ $25,6^{\circ} \mathrm{C}$. Pada siang hari kisaran suhu di wilayah RTH sebesar $27,9-29,9^{\circ} \mathrm{C}$, sementara di wilayah non-RTH $35,0-35,3^{\circ} \mathrm{C}$. Pada sore hari di wilayah 
RTH sebesar $25,9-27,3^{\circ} \mathrm{C}$, sementara di wilayah non RTH sebesar $27,5-27,8^{\circ} \mathrm{C}$ dan suhu udara harian di wilayah RTH sebesar $25,2-26,6^{\circ} \mathrm{C}$, di wilayah nonRTH berkisar antara $28,1-28,5^{\circ} \mathrm{C}$.

Secara umum hasil yang diperoleh menunjukkan bahwa kawasan RTH akan memberikan pengaruh cooling effect di daerah sekitar sehingga suhu udara yang dimiliki akan lebih rendah dibandingkan dengan kawasan non-RTH. Semakin besar suatu kawasan RTH maka pengaruh cooling effect yang terjadi akan semakin besar sehingga semakin luasnya RTH akan memiliki suhu udara yang semakin rendah, khsusnya di siang hari RTH area lebih dingin $0,9-1,0^{\circ} \mathrm{C}$ dibandingkan dengan RTH titik. Kondisi lingkungan di RTH seperti kerapatan penutupan kanopi pohon di sekitar area, kondisi lalu lintas di sekitar RTH, dan objek di sekitar dan di dalam RTH menjadi faktor yang menyebabkan melemahnya pengaruh cooling effect di daerah tersebut.

Hasil yang didapat pada penelitian ini menunjukkan bahwa RTH memiliki pengaruh positif terhadap kenyamanan termal, khususnya saat pagi, sore. Namun kondisi siang hari menunjukkan semua lokasi tidak nyaman, menjelaskan RTH yang masih kurang di kota Yogyakarta. Naungan yang diberikan oleh RTH memberikan nilai THI yang nyaman. Oleh karena itu keberadaan RTH di perkotaan sangat penting untuk mengendalikan iklim mikro di perkotaan sehingga mendukung kondisi yang lebih nyaman di sebuah kota.

\section{DAFTAR PUSTAKA}

Cohen P., Potchter O. and Matzarakis A. 2012. Daily and Seasonal Climatic Conditions of Green Urban Open Spaces in the Mediterranean Climate and Their Impact on Human Comfort. J Building Environment. 51:285-295.
Departemen Dalam Negeri. 2007. Undang-undang Republik Indonesia Nomor 26 Tahun 2007. Tentang: Penataan Ruang.

Effendy S., Bey A., Zain A.F.M. dan Santosa I. 2006. Peranan ruang terbuka hijau dalam mengendalikan suhu udara dan urban heat island wilayah JABOTABEK. J Agromet Indonesia, 20(1): 23-33.

Effendy S. 2009. Dampak pengurangan ruang terbuka hijau dalam mengendalikan suhu udara dan urban heat island wilayah JABOTABEK. J Agromet Indonesia. 23(2):169-181.

Gomez F., Gil L. and Jabaloyes J. 2004. Experimental investigation on the thermal comfort in the city: relationship with the green areas, interaction with the urban microclimate. $J$ Building and Environment. 39:1077-1086.

Handoko. 1993. Klimatologi Dasar. Jakarta: PT Dunia Pustaka Jaya.

Kakon A.N., Nobuo M., Kojima S. dan Yoko T. 2010. Assessment of thermal comfort in respect to building height in a high-density city in the Tropics. J Engineering and Applied Sciences. 3(3):545-551.

Oliveira S., Andrade H. and Vaz T. 2011. The cooling effect of green spaces as a contribution to the mitigation of urban heat: A case study in Lisbon. $J$ Building and Enivironment. 46:2186-2194.

Setyowati D.L. 2008. Iklim mikro dan kebutuhan ruang terbuka hijau di Kota Semarang. J Manusia dan Lingkungan. 15(3):125-140.

Shahidan M.F., Shariff M.K.M., Jones P., Shalleh E. and Abdullah A.M. 2010. A Comparison of mesua ferrea L. and hurra crepitans L. for shade creation and radiation modification in improving thermal comfort. $J$ Landscape and Urban Planning. 97:168-181.

Tjasyono B. 2008. Meteorologi Terapan. Bandung: Penerbit ITB.

Walikota Yogyakarta. 2007. Keputusan Walikota Yogyakarta Nomor 619 Tahun 2007 Tentang: Rencana Aksi Daerah Peningkatan Kualitas Lingkungan Kota Yogyakarta Tahun 2007-2011. 